\title{
Phytoreclamation of Abandoned Acid Mine Drainage Site After Treatment with Fly Ash
}

\author{
Madhumita Roy, Roopali Roychowdhury, \\ Pritam Mukherjee, Atanu Roy, Bulti Nayak and \\ Satarupa Roy
}

Additional information is available at the end of the chapter

http://dx.doi.org/10.5772/intechopen.69527

\begin{abstract}
Acid mine drainage and coal fly ash both are the sibling products from man's increasing demand for power. Mining of coal from coal mines generates acid mine drainage (AMD), and burning of coal for thermal power generation produces fly ash (FA). Although both are hazardous to the ecosystem and human health, reunion of them into one would reduce their toxic effect on nature. Mining causes exposure of hidden rock materials containing an abundance of sulphide to the atmosphere. Oxidation of the metal sulphides (pyrite, as iron sulphide) within the surrounding rock and overburden generates acidity. Subsurface mining that pumps out water to prevent flooding releases acidic water to nearby areas, known as acid mine drainage. Tailings piles, mine waste rock dumps, and coal spoils contribute in AMD. Improper disposal of the fly ash contaminates the soil, water and air by leaching of the pollutants or air borne particulate matters. However filler properties and presence of macronutrients makes fly ash an excellent filler material for mine sites, and its soil-like properties help in plant growth if provided with organic carbon and nitrogen. This chapter proposes development of a green cover into AMD site after treatment of the AMD site with FA.
\end{abstract}

Keywords: acid mine drainage, fly ash, phytoreclamation, green capping, biofuel

\section{Introduction}

Acid mine drainage (AMD) and fly ash (FA) from coal-based thermal power plants have been recognized worldwide as major environmental problems caused by mining industries across the globe. But FA although a hazardous waste product has great beneficiation property for 
reclamation of other degraded landscapes like AMD sites. Mining activities accelerate the acid mine drainage by exposing sulfide-containing rocks to the weathering process. Mine tailings (byproducts leftover from mining), mine waste rock dumps, and coal spoils/overburdens all are contributing factors to acid mine drainage. Certain minerals like sulfides of iron (pyrite, $\mathrm{FeS}_{2^{\prime}}$ and pyrrhotite, Fe1-XS) present in the rocks remain stable and insoluble until they come in contact with atmospheric oxygen and water. But upon exposure to water and air, they react to form sulphuric acid. This acid further causes dissolution of harmful heavy metals from the rocks. The heavy metal-loaded acid is carried off by rainwater or surface drainage to the nearby streams, rivers, or lakes, creating environmental risks. As the flowing water mixes with mine wastes and other mining leftovers, it picks up metals and other substances that pollute the water posing serious threats to ecosystems. Iron is an important metal in the AMD process. Combined with sulfate and/or sulfide, a yellow-orange solid colloquially known as yellow boy is produced which if deposited into streams can disrupt stream ecosystem. Acid mine drainage is a big problem in areas where abandoned mines are common. Processes that affect the release and transport of trace metals have to be known in order to achieve effective management and amendment of AMD and its consecutive impacts. FA from burnt coal contains certain heavy metals and nonmetals, which are otherwise hazardous if not properly disposed. The deleterious effects of AMD and FA have been studied earlier by many researchers. Tons of these wastes generated each day have certain characteristic features which can help in treating AMD. It has been reported that the acidic AMD has a $\mathrm{pH}$ of $2-4$, along with a high sulfate concentrations (1-20 g/l). The mineralization and extremely acidic $\mathrm{pH}$ levels cause toxicity of these wastes, which are not only environmentally damaging but also require expensive storage, remediation, and disposal techniques. Fly ash on the other hand is alkaline in nature due to its constituent lime fraction along with other metal components. Many studies have found fly ash a very good neutralizing agent compared to chemical-neutralizing agents such as lime, slaked lime, calcium carbonate, sodium carbonate, sodium hydroxide, and magnesium oxide and hydroxide whose cost and effectiveness remain questionable [1]. Fly ash generated by coal-based thermal power plants provide ample amount of cheap resource which on successful implementation on AMD will address two main issues:

- The reduction of the AMD treatment cost.

- The effective management of FA.

As compared to the conventional processes of AMD neutralization, which have their own pros and cons, the cost involved in FA application is less. FA is freely available in close adjacency to coal mines generating AMD which even reduces the cost of transfer when mines are placed in close proximity. Millions of tons of FA generation are a matter of concern regarding proper disposal, as it poses environmental threats. Treating AMD with FA is like killing two birds with single stone. It can be effectively used to fill mine spoils and remediate acidic soils. From a pH range of 2.5-2.7, AMD can be neutralized to a $\mathrm{pH}$ of 7.0 with fly ash.

Increasing the $\mathrm{pH}$ and immobilizing the metal contaminant elements as amorphous hydroxides or oxyhydroxides, fly ash is an excellent option which contains substantial amounts of silicon dioxide $\left(\mathrm{SiO}_{2}\right)$ (both amorphous and crystalline), aluminum oxide $\left(\mathrm{Al}_{2} \mathrm{O}_{3}\right)$, and calcium oxide $(\mathrm{CaO})$. Liming process requires further treatments with flocculants and biological 
procedures for sulfate reduction, whereas soluble residues are produced when AMD is treated with FA which needs disposal. If FA is utilized in acid mine water neutralization, it can curb the additional costs of conventional chemical treatments. This will not only prove to be cost-effective but also treat and dispose both AMD and FA in an easy way. Treatment of AMD with FA not only controls acidification process but also helps in proper utilization of FA generation. Experimental procedures with FA in AMD neutralization have revealed that a predetermined mixture of acid mine water and fly ash when continuously stirred at room temperature and pressure at a specific fly ash to acid mine water ratio (AMD-FA) of 3:1 for 30 min resulted in $\mathrm{pH}$ increase toward making it alkaline. From a $\mathrm{pH}$ range of 2.5-2.7, AMD can be neutralized to a $\mathrm{pH}$ of 7.0 with fly ash [2]. FA has been used successfully in controlling mine drainage water through construction of a constructed wetland [3], mine backfilling [4,5], and reclamation of abandoned open cast mine sites [6] and abandoned, underground coal mines [7]. However, the present chapter would discuss application of FA for phytoreclamation of abandoned mine sites. Mining is a temporary use of land, with the life span of an active mine ranging from few years to several decades. Before the 1970s, it was a common practice for mining companies to leave mine sites in its present state. However, now it is mandatory that mine closure would require the reclamation or rehabilitation of decommissioned mine sites, which involves returning the land and watercourses to an acceptable standard. Reclamation is the process by which degraded lands are returned to productivity and by which some measures of biotic function and productivity are restored. Various types of reclamation activities which are in use includes removing or remediating hazardous materials, reshaping the land, restoring topsoil, and planting native grasses, trees, or ground cover. Sometimes the methods used remain inadequate for the complete prevention of environmental contamination, and the mines are therefore considered to be improperly reclaimed by today's standards. Some abandoned mines are announced as "orphaned" - as the owners cannot be traced or in cases where the owner rejects to clean the mine site. In those cases, governments decide to close and rehabilitate orphaned and abandoned mines. Phytoremediation (phyto stands for plant and remediation stands for removal or correction of an evil) is a technology that uses various plants to extract, contain, degrade, or immobilize contaminants from soil and water. This technology has been receiving increasing attention for remediation of hazardous waste sites as an innovative, cost-effective, environment-friendly alternative to other treatment methods. Although phytorestoration has been successfully used for reclamation of FA ponds, phytorestoration of acid mine drainage has not been tried. The present chapter discusses the problems associated with direct phytoremediation of AMD soils. The extreme acidic $\mathrm{pH}$ and high sulfate concentration would not be able to provide environment for plant growth. Although few native species of plants have been found in different countries that grows in acidic soils [8], most plants studied suitable for phytoremediation would not grow in AMD sites. But it may be noteworthy to say that the AMD treated or filled with FA would present a suitable matrix for plant growth. In addition to the high concentration of plant essential nutrients such as $\mathrm{Fe}, \mathrm{Zn}, \mathrm{Cu}, \mathrm{Al}, \mathrm{Mn}$, etc., which are already present in coal burned fly ash, amendment with biofertilizers and mycorrhizas can accelerate phytocover development. Soil productivity can be increased by amending soil with many types of natural materials such as animal manures, saw dust, sewage sludge, wood residues, etc. These materials stimulate the microbial activity and provides $\mathrm{N}, \mathrm{P}$, and organic carbon to the soil. The phytocover would 
not only have esthetic value but would also be economically profitable in long terms through cultivation of bioenergy/biofuel crops. The role of certain microorganisms (bioremediation) also has been reported which can inhabit in acidic and alkaline environment and can participate in the reclamation process [9]. They have heavy metal-accumulating properties and are capable of biotransforming them into a less toxic form. This property of heavy metal reduction by microorganisms has been widely studied and accepted by many researchers. Certain rhizobacteria (bacteria inhabiting root system of plants) are there which are heavy metal tolerant and have various plant growth-promoting features [10]. Bioaugmenting those bacteria in the site would serve additional benefits. Exclusive properties of FA as a niche for certain heavy metal-resistant bacteria would prove it to be an excellent stride towards an ecofriendly effort of better AMD beneficiation.

\section{Hazards from the two by-products of mining industries}

Power generation in most countries is largely dependent on thermal power plants, and they are dependent on coal, a product from mining industry. On the other hand, coal mines and other types of mines are source of acid mine drainage (AMD). Both types of byproducts from the mining industry are deleterious to environment if not managed properly. Following is a discussion on the hazardous nature of coal fly ash (ash derived from coal burning) and AMD.

\subsection{Ecosystem and health hazards from coal fly ash}

Coal ash is the leftover waste after combustion of coal. It includes fly ash (fine powder-like particles that are driven out from the boiler of thermal power plants with the flue gases and are captured by pollution control devices) and other coarser materials that drop to the bottom of the furnace. Coal ash typically contains toxic heavy metals including arsenic, lead, mercury, cadmium, chromium, and selenium and sometimes radioactive wastes as well. The Environmental Protection Agency (EPA) has warned that living next to a coal ash and particularly unlined wet ash pond (surface impoundment) disposal site can increase risk of cancer or other diseases. Leaching of heavy metals from dump grounds to the underground water reservoir may contaminate drinking water supply with arsenic and other heavy metals. If eaten, drunk, or inhaled, the air-borne toxicants released from thermal power plants or landfills or ash ponds can cause cancer and several other diseases effecting the nervous system (cognitive deficits, developmental delays, and behavioral problems), respiratory damage of the heart and lungs, kidney disease, reproductive problems, gastrointestinal illness, and birth defects. The EPA estimates that 140 million tons of coal ashes are generated annually. Arsenic is one of the most common, and most dangerous, pollutants from coal ash. The EPA also found that living near ash ponds increases the risk of damage from cadmium, lead, and other toxic metals.

A giant spill occurred in Kingston, TN, just before Christmas 2008. More than a billion gallons of water and coal ash spilled into the neighboring river valley. EPA found arsenic at 149 times the allowable standard for drinking water in the water, as well as elevated levels of other toxic metals including lead, thallium, barium, cadmium, chromium, mercury, and nickel. Another 
case study of leaching hazards from FA dump occurred in Niagara (NY) Mohawk Power Corporation on Lake Erie. The drinking water wells were severely contaminated with leached lead which is a very potent neurotoxin that can harm the developing nervous system, even at low levels of exposure. Another case of contamination from use as "fill" occurred at a 216-acre golf course in Chesapeake, VA, where 1.5 million cubic yards of fly ash were recycled to give contour to the course. When groundwater at the golf course was tested, arsenic, boron, chromium, copper, lead, and vanadium were detected.

\subsection{Ecosystem and health hazards from open cast, underground, abandoned, and other types of mines}

\subsubsection{Open cast mining}

In open cast mining, material to be mined is excavated from an open pit. This type of mining is the most common type of mining for obtaining strategic minerals. This type of mining is very environmentally hazardous as strategic minerals are normally available in small amounts, which increases the amount of ore needed to be mined. Hard-rock mining causes rock exposure. When these rocks are crushed, radioactive elements, asbestos-like minerals, metallic dust, and other toxic elements get exposed. During separation, residual rock slurries, which are mixtures of pulverized rock and liquid, are produced as tailings, toxic and radioactive elements from these liquids can leak into bedrock if not properly contained.

\subsubsection{Underground mining}

Underground mining is very dangerous as it has the potential for tunnel collapses and land subsidence. It involves large-scale movements of waste rock and vegetation, similar to open pit mining in addition to releasing a variety of toxic compounds into the environment. As water takes on harmful concentrations of minerals and heavy metals, it becomes a contaminant. This contaminated water can pollute the region surrounding the mine and beyond. Most underground mining operations increase sedimentation in nearby rivers through their use of hydraulic pumps and suction dredges; blasting with hydraulic pumps removes ecologically valuable topsoil containing seed banks, making it difficult for vegetation to recover. Underground mine also causes deforestation leading to land erosion.

\subsubsection{In situ leach (ISL) mining}

ISL mining in the best type of mining over conventional mining in that the ore body is dissolved and then pumped out, leaving minimal surface disturbance and no tailings or waste rocks (World Nuclear Association, 2012). There is no formation of ore dust, and a lower water consumption is required [11]. But the use of strong acids for dissolving the ore body also dissolves metals in the host rock body. The fluids retained after the leaching process is also dangerous to the nearby ground and surface water sources as it contains elevated concentrations of heavy metals and radioactive isotopes [11]. Additionally, the acid-containing ISL mining wastewater can result in significant acidification of the surrounding environment if not neutralized by neutralizing agents. 


\subsubsection{Abandoned mines}

Abandoned mines are areas where mining activities once occurred, but proper mine closure and reclamation did not take place or were incomplete. Ineffective enforcement on mine reclamation policy and minimal penalties for noncompliance were the main contributing factors for the large numbers of abandoned mines present today. Mines were used to be abandoned for various reasons such as reduction in the price of mining minerals, unforeseen disaster that caused bankruptcy of the mining company, national security issues in times of conflict leading to the rapid development of a number of mines without proper operations or closure requirements, political unrest causing the unscheduled halt of mining operations and small-scale illegal mining, etc. Although abandoned they still continue to release toxic products from the leftover mining residues, underground workings, open pit mine faces, waste rock piles, and tailings storage areas to the nearby lands and water bodies for a long time. The majority of the AMD actually comes from inactive or abandoned mines [12]. Until the 1970s, there was a lack of mine reclamation policies. However, nowadays most countries have adopted strong regulations according to which mining companies have to provide specific mine closure plan before their mining project is approved.

\section{Physical and chemical methods of AMD treatments with their inherent advantages and disadvantages}

Physical and chemical procedures of AMD treatment include prevention of AMD drainage by the following processes involved:

- Surface water diversion

In this technique, the water supply to certain acid-generating materials is reduced by the use of safeguard channel pipes, slope changes, and water proof channels.

This technique should be applied after a thorough study of hydrological and hydrogeological area, generally lack of which results in an inappropriate application of this procedure. Sometimes due to surface water diversion, certain less acid-producing areas receive less water, leading to extreme acid production. However, being a cheap technique and easily applicable, it works well in collaboration with other techniques.

- Dry covers

Dry cover application aims at achieving two different objectives:

(1) Prevention of erosion by wind and water, by stabilization of mine wastes.

(2) Pollutant releases inhibition and prevention which can be achieved by preventing oxygen and water penetration in wastes. Oxygen deficiency decreases microbial oxidation of sulfides. Different covering materials such as soil, rock, or any cement-like materials form a crust. The cover must be capable of providing prolonged protection. Figure 1 shows a layout of a dry cover generation (reproduced from Johnson and Hallberg [13]). 
Different types of materials are used for dry cover. Advantages and disadvantages of different materials used for dry covers are displayed in Table 1.

Sludges combined with certain inorganic covers improve the sealing properties and physical conditions of the soil. In promoting vegetation cover, it prevents erosion improving the appearance of the area.

- Sealing with clay

A convenient coating in the mine holes with clay avoids acid transfer through groundwater discharge. This reduces the water input in mining wastes. Sometimes inland water pits are made in the mines which contain the acidic water acting as a reservoir for the same. This scenario is quite common in abandoned mines, which needs remedial techniques; hence sealing is a desirable option.

\subsection{Chemical procedures}

Alternatively, neutralization of AMD is carried out by application of chemicals. Abatement of these unfriendly wastes is possible according to studies. Today there are many methods that are in practice on active mine sites to prevent this from happening. This includes capping of waste piles, having on-site treatment with constructs like limestone trenches [14].

The most widespread method used to mitigate acidic effluents is an active treatment process involving addition of a chemical-neutralizing agent $[15,16]$. Addition of an alkaline material to AMD will raise its $\mathrm{pH}$ and accelerate the rate of chemical oxidation of ferrous iron.

Earlier, various chemicals including lime, slaked lime, calcium carbonate, sodium carbonate, sodium hydroxide, and magnesium oxide and hydroxide have been used to overcome the acidic fractions as a procedure. However, their cost and effectiveness remain questionable. As reported earlier by scientists, sodium hydroxide is 1.5 times effective in neutralization as compared to lime but remains a dearer option. Diminishing lime reserves and costing systems remain as issues for treatment of AMD along with the formation of ferric oxyhydroxide mantle, thereby compelling researchers to explore different options.

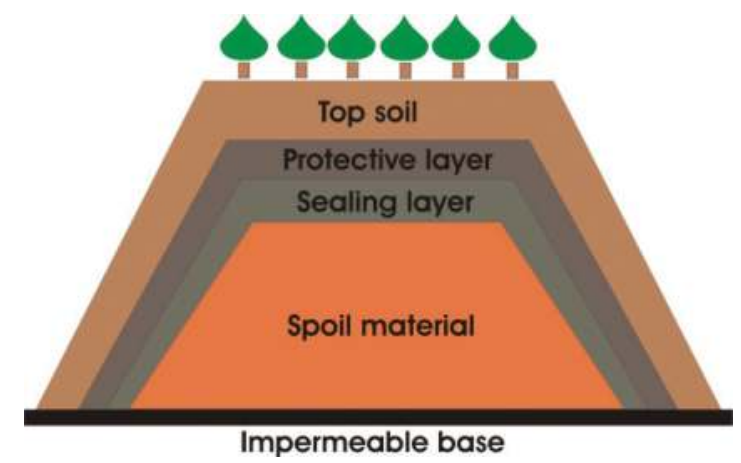

Figure 1. Layout of a dry cover for reduction of mine spoil effluents (source: Johnson and Hallberg [13]). 


\begin{tabular}{|c|c|c|}
\hline Material & Advantages & Disadvantages \\
\hline PVC sheet & $\begin{array}{l}\text { Completely impermeable } \\
\text { Low installation costs }\end{array}$ & $\begin{array}{l}\text { Capable of boring } \\
\text { Relatively expensive }\end{array}$ \\
\hline Grout & $\begin{array}{l}\text { Lower price } \\
\text { Low installation costs }\end{array}$ & $\begin{array}{l}\text { Susceptible to weathering } \\
\text { Undefined compaction/permeability } \\
\text { rate }\end{array}$ \\
\hline Clays (bentonite) & $\begin{array}{l}\text { Durable } \\
\text { Cheap and available }\end{array}$ & $\begin{array}{l}\text { Undefined } \\
\text { compaction/permeability rate } \\
\text { Dry conditions required for } \\
\text { application }\end{array}$ \\
\hline Asphalt & Fully impermeable & $\begin{array}{l}\text { Expensive material } \\
\text { High installation costs } \\
\text { Liable to deformation }\end{array}$ \\
\hline
\end{tabular}

Table 1. A comparative analysis of the advantages and disadvantages associated with different materials used for dry cover.

The studies regarding interaction of certain chemicals with tailings, and reduction in acid release and iron and other heavy metals' solubility decrease with the increase in $\mathrm{pH}$, have been reported. Certain inexpensive alkaline chemicals can be added to these mining wastes, which would be beneficial in neutralization of acid $\mathrm{pH}$ in mining wastes. But the recurrence of acidification remains an issue.

Limestone shallow pits known as leach beds are filled with limestone chips and stone, adding alkalinity to the passing water. However, the water for treatment must be diverted toward it and should have a passage out after a waiting time. Fairly easy to construct, it seems a wetland with stone bed which is not deep. Figure 2 shows the use of limestone for reducing the acidity of an AMD site.

Liming process involves application of a lime layer to produce an alkaline environment inhibiting bacterial growth and partial neutralization of the acid. Being a cheap alternative, the practice is highly applicable; however, the neutralizing potential becomes challenging and interrupted on deposition of iron hydroxide layer on the surface, in extreme acidic conditions. Deposition of iron on the limestone reduces its ability to neutralize the acid. Removal of this iron is necessary as its role in leaching is customary. Iron removal from solutions is achieved by precipitation with siliceous materials like furnace slag, portland cement, and fly ash. Oxidation inhibition lessens the amount of ferric ion reacting with pyrites. Various types of alkaline chemicals can be added in the mine wastes to decrease the release of acid, iron, and other metals from the waste deposit. They will neutralize the acid, and as many metals have a lower solubility at higher $\mathrm{pH}$, the release of heavy metals from the mine waste would also decrease. Figure 3 shows addition of chemicals over mine waste.

\subsection{The use of bioreactors}

Utilization of microorganisms for active metal precipitation is the key concept of certain bioreactors, which do not require water diversion. 


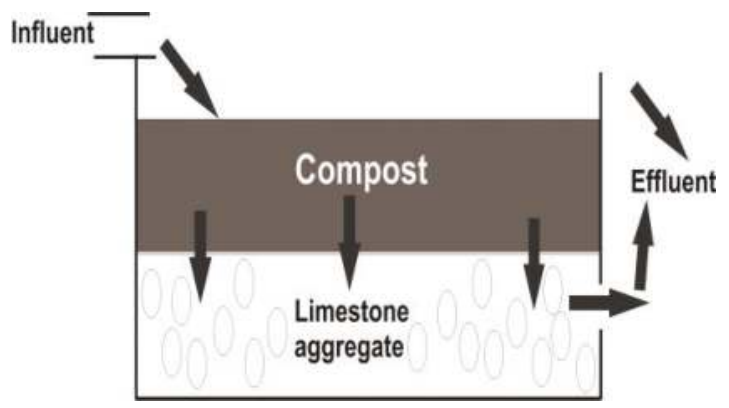

Figure 2. Schematic layout of a reducing and alkalinity producing system (RAPS), redrawn after Younger et al. [17] and Johnson and Hallberg [13].

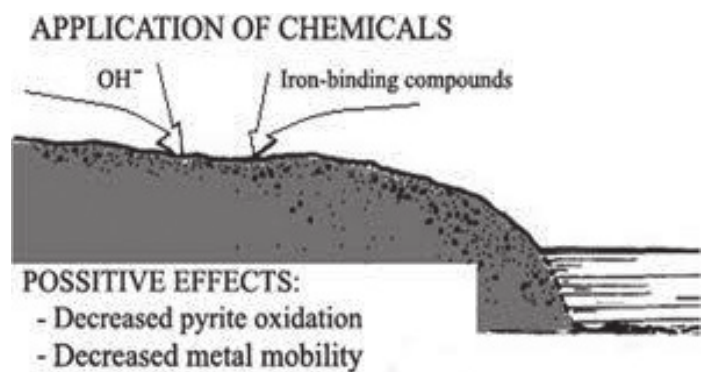

Figure 3. Treatment of solid mine waste with chemicals (redrawn from Ledin and Pedersen [9]). Application of chemicals on mine waste reduces leaching of heavy metals and decreases acid production from pyrite oxidation (source: Ledin and Pedersen [9]).

\section{Treatment of acid mine drainage with fly ash: killing two birds with a single stone}

Fly ash for reclamation of abandoned coal mine is an environmental approach, which is the most viable option for maximum utilization of disposed ash. Saving land requirements for ash dumping, reclamation also proves to be a better choice for gainful use of reclaimed mines.

Bulk quantity of fly ash can be utilized in lying of underground mines and open cast mine voids with preference, compared to sand [18, 19]. Backfilling of mines provides support to pillars and walls and helps reduction of void volume in underground coal mines. Studies suggest greater stability of backfilled mines than non-backfilled ones. FA works as a backfilling material effortlessly due to its pozzolanic nature which has low permeability with respect to soil or other mine wastes, thereby reducing the chance of chemical leaching. AMD generation and sinking in are reduced in FA backfilled mines, and the substituent solid residues generated remain strongly alkaline and possess pozzolanic properties. Fly ash can be an inherent 
candidate for mine reclamation due to its unique properties of alkaline nature, easy flowing capable as filler, good water holding capacity initiating afforestation, and a good soil ameliorant [20-22].

However, coal fly ash beneficiation in the case of AMD requires the below-listed criteria, studies of which have been acclaimed toward utilization of coal ash on active mine site. Before ash placement, certain procedural sequential steps need to be taken which would suggest successful ash placement in acid mine reclamation projects. Fly ash contains:

- Alkaline condition

- Low permeability

- Soil substitute or additive qualities

- A placement alternative

Alkaline quality generates alkaline leachates and is further used to counteract the ability of onsite materials to generate AMD. However, it is recommended that a neutralization potential and $\mathrm{pH}$ ranging between 7.5 and 12 are available. For proper utilization of fly ash having pozzolanic properties and low permeability, it is important that the permeability under lab conditions be equal to or less than $1.0 \times 10^{-6} \mathrm{~cm} / \mathrm{s}$. The alkaline nature makes fly ash a good soil cover for the soil or soil substitute where it acts as a liming agent. Coal fly ash acts as an ameliorant and improves the characteristics of soil when the soil ash mixture contains a $\mathrm{pH}$ of 6.5-8.0. This $\mathrm{pH}$ is ideally the most acceptable to attain growth medium. Backfilling of pits and recontouring refused piles make utilization of FA known as ash placement. In short coal ash is beneficial in many ways, acting as a capping agent, for placements and a soil additive or enhancer.

The application and use of fly ash on-site follow certain guidelines before approval which involve detailed application for utilization of fly ash, purpose and amount of requirement, and above all details of handling and incorporation at the project site. A clear outline and indication stating the ash is physically and chemically fit for utilization are mandatory. Collection of background data and written specifications regarding hydrogeological study of the ash utilization area is required to monitor the effect of ash on surface and groundwater quality.

Before application of ash on-site, a chemical analysis on dry weight basis has to be performed (testing of metals and $\mathrm{pH}$ ). Similarly, leachate tests by SPLP synthetic precipitation leach procedure has to be conducted for $\mathrm{pH}$, sulfate, chloride, and other metals. As long as the ash is used on the mine site, periodic recertification or monitoring is required to ensure ash quality. Sometimes a mixture of bottom ash and fly ash is considered for use on-site; in such cases both the ash quality tests should be provided before utilization. A detail soil analysis report which provides data on $\mathrm{pH}, \mathrm{PCB}$, and different heavy metals and nonmetals and trace elements (micro and macro) including arsenic, cadmium, copper, chromium, lead, etc. is required when the proposed utilization of ash is in the form of a soil additive. This leads to the possibilities known for efficient plant take-up process [23]. 
Ash application on all site areas requires groundwater monitoring, except those where the motive of ash application is just as a soil additive, because the amount of ash addition is comparatively less. However, in all other mines, groundwater monitoring is required before and at the time of application and after ash placement. Monitoring of groundwater includes monitoring wells where there are insufficient groundwater discharge points.

Ash monitoring points should be sampled time to time so as to meet the standard mine drainage parameters along with certain metals like aluminum, cadmium, calcium, selenium, etc. A time interval for monitoring on quarterly basis is required for mine drainage parameters and annually for chlorides and additional existing metals. Moreover, some sites might require additional monitoring. On completion of the site, monitoring continues until all parameters are assessed as stable. Ash placement is done not less than and within 8 feet on top of the groundwater table of that region.

Coal ash utilization for mine reclamation takes into consideration the following special coal ash conditions:

- Grading the disposal area for a stable base.

- Coal ash disposal area should be free from invading waters at all times.

- Moisture content of the ash must be under permissible limits so as to have $90 \%$ minimum compaction.

- Deposition of coal fly ash should not be within 8 feet of any vein or seam, pit floor or any coal outcrop, or groundwater elevation.

- Chemical and leachate analysis should be conducted for coal ash on regulatory basis.

- Modified proctor or standard proctor tests should be done for all coal ash in order to check for moisture content and $95 \%$ of maximum dry density.

- Water quality monitoring on quarterly basis.

- Minimum of 4 feet should be the final ash disposal area.

- To ensure proper field compaction, field density tests have to be performed.

- Finally, all coal ash conveyed to the ash disposal areas must be spread in lifts of 2 feet or less.

The abovementioned measures not only ensure mine reclamation but also indulge in wise disposal and utilization of a waste product into a proposed, eco-restored site at no extra cost. This wise adaptation of acid mine filling also helps in afforestation of the otherwise deserted land.

In summary, FA gives following benefits for reclamation of AMD sites:

(1) The alkaline nature of FA is ideal for seal or fill material of mining sites and can prevent the generation of acid mine drainage. 
(2) FA is a very good substrate for agricultural application to produce artificial soil on abandoned mine lands where native soils are not available.

(3) The acid-producing materials in the spoil can be neutralized by this alkaline amendment.

(4) A flowable fill seals and stabilizes abandoned underground mines to prevent subsidence and the production of acid mine drainage.

(5) Cost of mine site reclamation can be reduced significantly with the use of adequately available FA. This also solves storage-related issues of FA as power plants always face problems on the storage of huge quantities of FA produced as a by-product of coal burning.

Example of a successful application of using FA for treating abandoned mine was shown by Maryland Department of Natural Resources Power Plant Research Program and the Maryland Department of Environment Bureau of Mines in 1995. They jointly launched an effort to prevent acid formation from abandoned, underground coal mines. They used large volume of coal combustion products (CCPs) from power plants to create flowable grouts. They injected $100 \%$ CCP grout into the Frazee Mine, located near Friendsville, Garrett County, MD, and showed that CCP grout mixture can be beneficially used for abandoned underground coal mines to reduce acid formation as well to fill mine voids. The CCP grout mixture appears to be a high-strength, low-permeability material that can easily control mine subsidence and has no negative impact on water quality [24].

\section{Posttreatment phytoreclamation of the abandoned mine}

After filling the AMD site with fly ash, the next strategy would be preparing it for development of a plant cover. Although FA has many plant growth-promoting macronutrients and micronutrients, it lacks organic carbon, nitrogen, and phosphorous. So prior to plantation development, addition of various supplementations such as organic manure, biofertilizer, vermicompost, etc., is necessary [25].

\subsection{Phytoremediation or phytoreclamation}

Phytoreclamation or phytoremediation can be defined by three basic processes [26]:

- Plant extraction or phytoextraction: Phytoextraction is the removal of contaminants from soil or water through plant uptake and accumulation within plant tissue (either underground or aboveground biomass or both). One subtype is rhizofiltration by which hydrophytes or hydroponically grown plants use their roots in water to uptake or absorb the pollutants from water and bioconcentrate or precipitate them in the root or translocate and store them in shoots or leaves.

- Phytodegradation: Phytodegradation is the degradation or metabolism of the xenobiotic compounds by plant processes or plant-associated enzymes, bacteria, and other microflora. The endophytes present within plant tissues occasionally degrade PAH 
compounds that plants uptake from soil or water. Sometimes plant enzymes degrade them totally or transform (incomplete degradation) them to a less toxic state.

- Phytostabilization: Phytostabilization is the in situ immobilization or containment of the contaminants in the plant rhizosphere zone. Plants with extensive root system can reduce soil erosion to a large extent and in this procedure immobilize the heavy metals and other compounds present in soil. It is an intermittent way to prevent leaching of harmful chemicals or heavy metals from entering groundwater.

Phytoremediation is a newly evolving field of science and technology that uses plants (grasses/ herbs/woody species) to clean up polluted soil, groundwater, and wastewater and through this procedure removes, contains, or renders contaminants such as heavy metals, metalloids, trace elements, organic compounds, and radioactive compounds. Phytoremediation is dependent on the extraordinary uptake capabilities or sequestration ability of plant roots. Following uptake plants can translocate and bioaccumulate them to shoots or leaves. Some pollutants also undergo phytodegradation, phytotransformation, and phytovolatilization too. Phytoremediation is environment friendly and inexpensive as it does not need expensive excavation and transport of polluted media, and this also reduces the risk of spreading the contamination and has the potential to treat sites polluted with more than one type of pollutant. Phytoreclamation of FA disposal grounds and ash ponds has been applied with documented successes [27]. It is fast becoming acceptable to the public and in most cases is less expensive than traditional treatment technologies such as incineration, bioslurry composting, etc.

\subsection{Production of a phytocover}

The initial phytocover development is generally made by growing a mat of grasses and legumes [28, 29]. Grass-legume cover by the native species (and sometimes invasive species) has become the most efficient method of choice as they can readily colonize the area and develop a thick vegetation mat within a short period of time. In the meantime, they enhance fertility of the soil (FA amended with nutrients), prevent erosion and emission of air pollutants, and also phytosequester the heavy metals. This paves way for long-term management and gradual restoration of the site. However, prior to consideration of phytoremediation, factors like studying characteristics of the substrate, properties of the plants and residual microbes, and effect of the phytocover that it would have on the nearby ecosystem should be studied. Natural succession on FA basins has been studied in different countries. Grasses are the primary colonizers in degraded soils as they are better tolerant to drought and other environmental stresses (e.g., xenobiotic compound load) and require fewer nutrients and proliferate rapidly. The fibrous nature of the grass roots is effective in slowing down erosion and preserving soil moisture. Their soil-forming characters eventually produce a layer of organic soil upon which other leguminous crops grow and add nitrogen. Grasses and legumes play great roles for formation of a nutrient-rich top soil. Native species of grasses have ready adaptability with the prevailing environmental conditions, increase soil fertility, have faster establishment, and provide a sustainable microclimate for establishment of commercially useful species. This gives economical return from the rehabilitation programs. The initial cover must allow the development of diverse self-sustaining plant communities. Recently, Pandey et al. [29, 30] and Żołnierz et al. [31] have enumerated various naturally 
growing species on FA deposits during initial colonization and 11 years after vegetation establishment. Some examples of naturally growing species are Saccharum munja [32], nonnodulated species Cassia siamea Lamk, nodulated species of chickpea [33], and Pteris vittata, a fern [34]. S. munja was termed as an "ecological engineer" due to properties such as firm ash-soil binding capability and stabilizes the ash dump surface. According to Pandey [35], Ricinus communis L., naturally growing grass species on FA land fill sites, is a suitable plant species for revegetation of degraded lands like mine sites or ash dump sites in tropical and subtropical climates. In addition to acting as carbon sequestrator, it has great commercial value as it is an industrially valuable castor oil yielding crop. It provides ecosystem benefits like carbon sequestration, heavy metal uptake and accumulation, phytodegradation of organochlorine pesticides, substrate quality enhancement, biodiversity conservation, and feedstock for biofuel production [36]. Ferns like P. vittata L., Ampelopteris prolifera (Retz.) Copel., Diplazium esculentum (Retz.) Sw. and Thelypteris dentata (Forsk.), etc. also grow well on FA without showing heavy metal-related toxicity symptom. Kumari et al. [37] reported that the fern T. dentata is also suitable for phytoremediation and can be used efficiently to revegetate FA landfills. Some woody tree species like Leucaena leucocephala, Dendrocalamus strictus, and Eucalyptus $s p$. have the potential power for revegetation of FA disposal sites. These tree species have huge economic importance. Some timber and plywood-yielding plants that have been used successfully in studies are Shorea robusta, Tectona grandis, D. sissoo, Bombax ceiba, Populus euphratica, and Eucalyptus tereticornis [38]. Examples of some fuel wood tree species recommended by some workers recommended for phytorestoration job are Acacia auriculiformis, Albizia lebbeck, Acacia nilotica, Casuarina equisetifolia, Cassia siamea, Dalbergia sissoo, and Prosopis juliflora. In addition to their economic importance, they have nitrogen-fixing properties and excellent growth characteristics in nutrient-limited conditions. Examples of plywood-producing tree species which also can be used to act as fuels are Eucalyptus hybrid, Eucalyptus globules, Melia azedarach, Populus deltoids, Tamarindus indica, and Syzygium cumini [39]. In a study by Carlson and Adriano [40], it was depicted that a new ecosystem can been created on alkaline and acidic FA dump sites with Platanus occidentalis (sycamore) and Liquidambar styraciflua (sweetgum), which are important timber trees.

Trees contribute greatly to the formation of self-sustaining nutrient-rich top soil formation through biological nitrogen fixation, maintenance of soil organic matter, and increasing water infiltration and storage and reduce loss of nutrients by erosion and leaching. They also improve soil physical structure through reduction of soil acidity and improvement of soil biological activity. Through plant litters and root exudates, nutrient cycle between soil and plants is established. Nitrogen is a major limiting factor of mine spoils, and regular addition of nitrogen-rich fertilizer may be required to maintain vegetation on mine sites. Introduction of legumes and other nitrogen-fixing species may solve this problem. Formation of a productive forest ecosystem from primary or secondary plant community serves as the habitat for biotic communities, establishes its own food-chain trophic levels, and allows biogeochemical cycles. Most tedious process of fly ash dump reclamation or mine site reclamation is the establishment of the initial colonizing grass species. After the initial establishment of grass cover, strategies such as additions of organic amendments and spreading of grass legume fodder seeds, forage legumes, tuft, or hardy grasses are an efficient choice for development of a forest community. 
The grass legume cover helps in the development of a vegetation mat in a small period of time when compared to the tree species. A reclaimed site can then be used for different purposes like agricultural use or agro-forestry or silviculture. Finally, evaluation must be carried out to determine the success of the reclamation and monitor the groundwater quality. It is to also necessary to determine how closely the reclaimed site functions, in comparison to similar undisturbed sites, as an ecosystem. Reclamation of abandoned mine land is a very complex process. Most researchers agree that reclamation success must be measured by several parameters since no individual parameter provides sufficient information for ecosystem reclamation [41].

\section{Conclusion}

Ecological restoration of abandoned mine spoil sites has become an important part of the sustainable development strategy in many countries. Long-term mine spoil reclamation requires the establishment of a stable nutrient cycle from plant growth and microbial processes. Application of FA would help formation of soil over mine spoil by neutralizing the acidity and adding other important properties of soil. Growth of grasses and legumes over this would further help in the formation of top soil and by stable nutrient cycling would return the land to its pristine condition that can survive as a self-sustaining ecosystem. A successful green cap on the mine site would control pollution, stabilize the site, and give visual and esthetic pleasure.

\section{Author details}

Madhumita Roy*, Roopali Roychowdhury, Pritam Mukherjee, Atanu Roy, Bulti Nayak and Satarupa Roy

*Address all correspondence to: biotech4job@gmail.com

Department of Biotechnology, Techno India University, Salt Lake, Kolkata, West Bengal, India

\section{References}

[1] Skousen J, Ziemkiewicz P, Yang JE. Use of coal combustion by-products in mine reclamation: Review of case studies in the USA. Geosystem Engineering. 2012;15(1):71-83

[2] Vadapalli VR, Klink MJ, Etchebers O, Petrik LF, Gitari W, White RA, Iwuoha E. Neutralization of acid mine drainage using fly ash, and strength development of the resulting solid residues. South African Journal of Science. 2008;104(7-8):317-322

[3] Machemer SD, Wildeman TR. Adsorption compared with sulfide precipitation as metal removal processes from acid mine drainage in a constructed wetland. Journal of Contaminant Hydrology. 1992;9(1-2):115-131 
[4] Williams D, Ramlackhan M, Spriggs D. Report on potential for backfilling bord and pillar voids using fly ash slurry. (2010). www.dnrm.qld.gov.au/_data/assets/pdf_ file/0007/262663/collingwood-park-report-appendix-c.pdf

[5] Horiuchi S, Kawaguchi M, Yasuhara K. Effective use of fly ash slurry as fill material. Journal of Hazardous Materials. 2000;76(2-3):301-337

[6] Hornberger RJ, Dalberto AD, Menghini MJ et al. Coal Ash Beneficial Use at Mine Sites in Pennsylvania. World of Coal Ash (WOCA); Proceedings 2005, World of Coal Ash (WOCA), Lexington, KY, April 11-15

[7] Petzrick P, Rafalko LG, Lyons C, Chiang SH (Ed.) (1996). An overview of the western Maryland coal combustion by-products/acid mine drainage initiative, Part 1 of 3 . United States: Pittsburgh Coal Conference

[8] Abreua MM, Tavaresa MT, Batista MJ. Potential use of Erica andevalensis and Erica australis in phytoremediation of sulphide mine environments: São Domingos, Portugal. Journal of Geochemical Exploration. 2008;96:210-222

[9] Ledin M, Pedersen K. The environmental impact of mine wastes - Roles of microorganisms and their significance in treatment of mine wastes. Earth-Science Reviews. 1996;41(1-2):67-108

[10] Rau N, Mishra V, Sharma M, Das MK, Ahaluwalia K, Sharma RS. Evaluation of functional diversity in rhizobacterial taxa of a wild grass (Saccharum ravennae) colonizing abandoned fly ash dumps in Delhi urban ecosystem. Soil Biology \& Biochemistry. 2009;41:813-821

[11] Environment Protection Authority (EPA). Annual Report on the administration of the Radiation Protection and Control Act 1982. 2005-2006. www.epa.sa.gov.au/files/8366_ radiation0506.pdf

[12] Johnson DB. Chemical and microbiological characteristics of mineral spoils and drainage waters at abandoned coal and metal mines. Water, Air, \& Soil Pollution: Focus, 2003;3: 47-66. doi:10.1023/A:1022107520836

[13] Johnson DB, Hallberg KB. Acid mine drainage remediation options: A review. Science of the Total Environment. 2005;338:3-14

[14] Skousen J, Foreman J. Water management techniques for acid mine drainage control. Green Lands. 2000;30:44-53

[15] Coulton R, Bullen C, Dolan J, Hallet C, Wright J, Marsden C. Wheal Jane mine water active treatment plant-design, construction and operation. Land Contam Reclam 2003;11:245-252

[16] Coulton R, Bullen C, Hallet C. The design and optimization of active mine water treatment plants. Land Contam Reclam 2003;11:273-279

[17] Younger PL, Jayaweera A, Elliot A, Wood R, Amos P, Daugherty AJ, et al. Passive treatment of acidic mine waters in subsurface flow systems: Exploring RAPS and permeable reactive barriers. Land Contamination \& Reclamation. 2003;11:127-135 
[18] Pradhan A, Deshmukh JP. Utilization of fly ash for treatment of acid mine water. Journal of Environmental Research And Development. 2008;3(1):137-142

[19] Reynolds K, Petrik L. The use of fly ash for the control and treatment of acid mine drainage, in: Proceedings of world of coal ash symposium 2005, Lexington, USA

[20] Gitari MW, Petrik LF, Etchebers O, Key DL, Iwuoha E, Okujeni C. Treatment of acid mine drainage with fly ash: Removal of major contaminants and trace elements. Journal of Environmental Science and Health Part A. 2006;41(8):1729-1747

[21] Gitari WM, Petrik LF, Etchebers O, Key DL, Okujeni C. Utilization of fly ash for treatment of coal mines wastewater: Solubility controls on major inorganic contaminants. Fuel. 2008;87(12):2450-2462

[22] Gitari WM, Somerset VS, Petrik LF, Key D, Iwuoha E, Okujeni C. Treatment of acid mine drainage with fly ash: Removal of major, minor elements, $\mathrm{SO}_{4}$ and utilization of the solid residues for wastewater treatment. In: International Ash Utilization Symposium, Center for Applied Energy Research, University of Kentucky. 2003. pp. 1-23

[23] Luptakova A, Ubaldini S, Macingova E, Fornari P, Giuliano V. Application of physicalchemical and biological-chemical methods for heavy metals removal from acid mine drainage. Journal of Biotechnology. 2010;150:252-253

[24] Guynn RL, Rafalco LG, Petzrick P. Use of a CCP Grout to Reduce the Formation of Acid Mine Drainage: 10-Year Update on the Winding Ridge Project. Presented at the World of Coal Ash Conference Proceedings, Lexington, Kentucky, 2007. http://www. flyash.info/2007/52guynn.pdf

[25] Juwarkarr AA, Jambhulkar HP. Restoration of fly ash dump through biological interventions. Environmental Monitoring and Assessment. 2008;139(1):355-365

[26] Cunningham SD, Lee CR. Phytoremediation: Plant-based remediation of contaminated soils and sediments. Bioremediation: Science and applications. Soil Science Society of America. 1995;43:145-156

[27] Mpofu K, Mushiri S, Mushiri K. An investigation into the effectiveness of coal ash in acid mine drainage (AMD) abatement. A case study of iron duke mine. International Researcher. 2013;2(3):49-65

[28] Prasad MNV. Engineered phyto-covers as natural caps for containment of hazardous mine and municipal solid waste dump sites-possible energy sources. In: Ozturk M et al (eds) Phytoremediation for Green Energy. Springer Netherlands. 2014. pp. 55-68

[29] Pandey VC, Prakash P, Bajpai O, Kumar A, Singh N. Phytodiversity on fly ash deposits: Evaluation of naturally colonized species for sustainable phytorestoration. Environmental Science and Pollution Research. 2014;22(4):2776-2787

[30] Pandey VC, Bajpai O, Pandey DN, Singh N. Saccharum spontaneum: An underutilized tall grass for revegetation and restoration programs. Genetic Resources and Crop Evolution. 2015;62:443-450 
[31] Żołnierz L, Weber J, Gilewska M, Strączyńska S, Pruchniewicz D. The spontaneous development of understory vegetation on reclaimed and afforested post-mine excavation filled with fly ash. Catena. 2016;136:84-90

[32] Pandey VC, Singh K, Singh RP, Singh B. Naturally growing Saccharum munja on the fly ash lagoons: A potential ecological engineer for the revegetation and stabilization. Ecological Engineering. 2012;40:95-99

[33] Pandey VC, Singh JS, Kumar A, Tewari DD. Accumulation of heavy metals by chickpea grown in FA treated soil: Effect on antioxidants. Clean-Soil Air Water. 2010;38:1116-1123

[34] Srivastava M, Ma LQ, Singh N, Singh S. Antioxidant responses of hyper-accumulator and sensitive fern species to arsenic. Journal of Experimental Botany. 2005;56:1335-1342

[35] Pandey VC. Suitability of Ricinus communis L. cultivation for phytoremediation of fly ash disposal sites. Ecological engineering. 2013;57:336-341

[36] Rissato SR, Galhiane MS, Fernandes JR, Gerenutti M, Gomes HM, Ribeiro R, Almeida MV. Evaluation of Ricinus communis L. for the phytoremediation of polluted soil with organochlorine pesticides. BioMed Research International. vol. 2015, Article ID 549863, doi:10.1155/2015/549863

[37] Kumari R, Kaur I, Bhatnagar AK. Enhancing soil health and productivity of Lycopersicon esculentum Mill. using Sargassum johnstonii Setchell and Gardner as a soil conditioner and fertilizer. Journal of Applied Phycology. 2013;25(4):1225-1235

[38] Ram LC, Jha SK, Tripathi RC, Masto RE, Selvi VA. Remediation of fly ash landfills through plantation. Remediation Journal. 2008;18(4):71-90

[39] Pandey VC, Abhilash PC, Singh N. The Indian perspective of utilizing fly ash in phytoremediation, phytomanagement and biomass production. Journal of Environmental Management. 2009;90:2943-2958

[40] Carlson CL, Adriano DC. Growth and elemental content of two tree species growing on abandoned coal fly ash basins. Journal of Environment Quality. 1991;20:581-587

[41] Sheoran V, Sheoran AS, Poonia P. Soil reclamation of abandoned mine land by revegetation: A review. International Journal of Soil, Sediment and Water. 2010;3(2):13 